\title{
Research on Innovation and Entrepreneurship Education System in Colleges and \\ Universities
}

\author{
Gao Feng \\ Department of Computer Information and Technology \\ Xi'an University of Technological Information \\ Xi'an, China \\ e-mail:athena_g@163.com
}

\author{
Wang Xuetong \\ Teaching Research Division, Office of Educational \\ Administration \\ Xi'an University of Technology \\ Xi'an, China \\ e-mail: xtwang@xaut.edu.cn
}

\begin{abstract}
With the reform of education system, innovation and entrepreneurship education is the development strategy driven by innovation in the country, it is an urgent need to promote economic quality, efficiency and upgrading, and It has become a new concept of educational development. Based on the current universal problems of innovation and entrepreneurship education, this paper makes a systematic and systematic construction of the idea cognition, training process, practice system, platform construction and guarantee mechanism of innovation and entrepreneurship education in colleges and universities. It is helpful to improve the quality of talent training and promote the employment of college students, and provides specific ideas for the development of innovation and entrepreneurship education in colleges and universities in china.
\end{abstract}

Keywords-component; Innovation and Entrepreneurship Education; Synergic Education

\section{INTRODUCTION}

Under the historical background of popular entrepreneurship and innovation, economic development and social requirement proposed higher demand to colleges and universities [1]. As the main forth to training innovation spirit, entrepreneurial consciousness and competence for undergraduates, colleges and universities need to deepen comprehensive reform, overall promote innovation and entrepreneurship education to improve the quality of talent cultivation, promote economic and society development. Therefore, carrying out innovation and entrepreneurship education has great significance.

But the training form of innovation and entrepreneurship education is monotony in colleges and universities. They simply organize student curricular academic science and technology works competition to excite innovation spirit and abilities of students. Only few students take part in these competitions. This training form cannot fully promote the innovation and entrepreneurship education

\section{PROBLEMS EXISTED IN INNOVATION AND ENTREPRENEURSHIP EDUCATION}

Based on the present situation of innovation and entrepreneurship education in colleges and universities, they all pay more attention to it, but many problems already exist.

\section{A. Perception of Innovation and Entrepre neurship}

\section{Education}

Most students and teachers simply think that taking part in curricular academic science and technology works competition and being the member of students science and technology association are the mainly way to improve innovation spirit[2]. Talent cultivation of colleges and universities emphasizes knowledge and ability of major, but neglect form values of innovation and entrepreneurship and student comprehensive quality. Utilitarian evaluation to innovation and entrepreneurship education popularly exists, because many people think innovation and entrepreneurship 
education equals to curricular academic science and technology works.

\section{B. Systematicness of Innovation and Entrepre neur -ship Education}

The work of innovation and entrepreneurship education is developed mainly by scientific and technological competitions and association activity. Based on the core elements of innovation and entrepreneurship education and the cognitive growth rules of the students, the emphases and difficulties of the development in the work of innovation and entrepreneurship education are expressed by the lack of process and integrity and Systematization and scientific and personalization in the designing of innovation and entrepreneurship education.

\section{CONSTRUCTION OF THE PROCEDURING AND THE} SYSTEMATIZATION OF INNOVATION AND ENTREPRENEURSHIP EDUCATION

\section{A. Improving Perception and Definituding Training Ideas}

In order to promote and deepen innovation and entrepreneurship education, achieve the goal of innovative talents training. First of all, the school should definitude the target and orientation of talent cultivation, what kind of talents should be cultivated, and what areas should be cultivated for talents. Secondly, set up innovation and entrepreneurship organizations to ensure innovation, entrepreneurship, education, organization, leadership, policy and implementation. Finally, the suitable soil of innovation and entrepreneurship will be cultivated in the school, the respect creation and paying attention to opening up and daring to take risks and tolerance of failure in innovative and entrepreneurship of campus culture will be formed. These can ensure innovation and entrepreneurship education be popularized, exposed to contact easy to contact, and can improve the key.

\section{B. Continual Improvement of Talent Training Scheme}

According to the "basic quality - professional ability innovation and entrepreneurship quality" progressive revision training program, talents training program will be revised. The construction of professional core courses will be strengthened, the proportion of discussion class will be increased, process assessment will be implemented, and the students' professional ability and innovative thinking will be cultivated[3].Setting up frontier courses of subject and specialty will arouse students' curiosity and innovation consciousness, setting up the course of introducing innovation and entrepreneurship will provide students with innovation and entrepreneurship methodology. Setting up innovation and entrepreneurship credits and be included in the graduation requirements, these will be an assessment index of graduation examination. In addition, the practice of construction curriculum system will be strengthened, practical teaching system over layer will be gradually formed from the basic skills training (basic experiment, engineering training) training to professional skills (professional experiment and course design), over to the engineering consciousness training (internship, scientific research and academic competition) and autonomy (project practice).

\section{Strengthen the Integration Education Mechanism In Class and After Class}

According to the teaching idea of "student centered, guiding by learning outcomes", we carry out the reform of classroom teaching methods, such as heuristic, training, discussion, and flipped teaching. Teachers should be encouraged to integrate teaching research and engineering practice into classroom teaching, while cultivating students' thinking and methods, it let more students have the opportunity to participate in the teachers' scientific research projects, the students' comprehensive application ability and innovative ability will be trained through practice[4].To strengthen the practical training system construction, to promote teaching by competition, to promote learning by competition, to promote the creation of competition, the work of innovation and entrepreneurship education will be normalized. Internet plus innovation and entrepreneurship competition of the student, college students' innovation and entrepreneurship project are the core of the creative, innovative and entrepreneurial competition system. 


\section{Setting up Innovation and Entrepreneurship Practice}

\section{Platform}

Practice is an effective way to cultivate innovative thinking and improve the ability of innovation, building practice platform is important significance to cultivate college students' innovation and entrepreneurial ability with regard to the cultivation of innovative and entrepreneurial ability of College Students. Relying on the school engineering training center, the virtual simulation experimental teaching center and experimental teaching demonstration center and all kinds of professional laboratories will be united, the practical training platform based on interdisciplinary and interdisciplinary and multidisciplinary will be built. Let students contact more information in the process of practice, innovation potential and practical ability will be stimulated. Establishing regulations to strengthen the managing of opening practice platform and guiding more undergraduates take part in activities of innovation and entrepreneurship. Information service platform need to be established to propagate entrepreneurship support policy and enterprise cooperation information, provide entrepreneurship lecture and successful case. At the same time, the information service platform plays the role of attracting students to take part in innovation and entrepreneurship activities. It is conducive to popularize innovation and entrepreneurship

\section{E. Construction Synergic Education Mechanism}

Cooperation between school and enterprises, school and school, school and government helps to improve talent cultivation quality[5]. High-quality teaching resources can be shared. Credits can be transferred interscholastically. Students acquire abundant learning resources through inter-scholastic cooperation. Undergraduates can master rich skills by practice in enterprise practical training base through the effective use of enterprise advantages resource. Engineering capability of teaching staffs can be improved through sending teaching staffs to practice in enterprise. Engineers of enterprise, venture $\mathrm{i}$ alumni and Enterprise executives can be invited to guide or give lessons for undergraduates. Innovation and venture tutor teams are formed through measures above. Around the local development needs, setting up practice and innovation platform which can share resources, exchange technology and dock project for venture teams by taking advantage of government policy

\section{F. Strengthening Guarantee System Construction}

An expert group needs to be constituted for innovation and entrepreneurship education. This group research on innovation education regularly and provide consulting service. A cooperative-work-group including correlation departments of a university need to be constituted to promote innovation and entrepreneurship education. These two groups play the role of decision, leading and implementation. Guidance and service center for innovation and entrepreneurship. This center integrates resources from inner and outer of a university and provides human resource and place support for undergraduates venture teams. Funds for venture teams need to be built by university to support undergraduates to carry out innovation and entrepreneurship practice.

\section{CONCLUSION}

With the popularity of innovation and entrepreneurship talents in the society, innovation and entrepreneurship education will be the general direction of the current comprehensive reform of higher education, it is the long-term focus of the work of colleges and universities. According to the actual needs of college students, the education and support of college students' innovation and entrepreneurship is of great significance for enhancing core competitiveness, improving students' practical ability, easing employment pressure and promoting students' self-development. But at present, there are still some problems in the innovation and entrepreneurship education in many colleges and universities, such as lack of knowledge, imperfect discipline construction, incomplete teaching staff and serious disconnection from practice, the relevant schools should take measures from various aspects, such as paying attention to innovation and entrepreneurship education courses, building a complete teaching system, strengthening the construction of teaching staff, and improving the incentive mechanism, it will be 
improve the students' ability of innovation and entrepreneurship, and provide more opportunities for college students to start their own business, it also sets up a solid foundation for entrepreneurship education in colleges and universities.

\section{REFERENCES}

[1] Wang Xuetong, Wang Hao, and Qin Chuan, "Research on strategy of innovation and entrepreneurship education," Education Modernization. Beijing, pp. 26-27, January 2017.
[2] Chen Yong, Pan Jiaqi, "Study on cultivation innovation sprit and abilities," China Higher Education Evaluation. Shanghai, vol. 2, pp. 49-51, Feburary 2014.

[3] Liu Xianjun,"Applied Talents' Cultivation in Colleges and Universities under the Innavation-driven Development Strategy," China Higher Education Research, Beijing, pp.1-4, October 2017.

[4] Fu Bajun,'The Academic Capital Transformation of Entrepreneurial University," China Higher Education Research, Beijing, pp. 32-34, August 2016.

[5] Wang Zhanren,"Argument snd Reflection on Promoting Innovation and Entrepreneurship Education in China's University," Research in Educational Development. Shanghai, pp.113-119, August 2015. 